\title{
Assessing livestock herding practices of agro-pastoralists in western Bhutan: Livestock vulnerability to predation and implications for livestock management policy
}

\author{
Kencho Tshering ${ }^{1}$ and Phuntsho Thinley ${ }^{2 *}$ (D)
}

\begin{abstract}
As in many developing countries, agro-pastoralism is the major form of livelihood for rural communities in the Himalayan Kingdom of Bhutan. Although livestock rearing is part and parcel of rural Bhutanese agricultural system, Bhutan also has a high percentage of natural forest cover that supports a diversity of endangered wild predators. The loss of cattle to these predators is an on-going source of conflict between predators, farmers, and wildlife managers. Despite awareness of predation losses, there has been no empirical assessment of livestock herding practices in Bhutan in terms of livestock vulnerability to predation. We conducted a questionnaire and a field survey in three districts of western Bhutan to assess current livestock herding practices with regard to predation vulnerability. We interviewed farmers using a semi-structured questionnaire to determine their livestock herding practices and losses. We also traversed human trails in the nearby forests and took note of livestock encountered to gain further insights into herding dynamics. Generally, livestock were more vulnerable to predation when released into the forests without accompanying herders. Seasonally, livestock were more vulnerable during summer and early autumn, which coincided with the peak farming period during which animals are typically released into forests with minimal care. Our study underscores the importance of livestock herding with accompanying herders to minimize predation losses and highlights the challenges posed by farm labour shortage in rural areas. We recommend developing a comprehensive livestock management policy that includes elaborate provisions on reducing livestock losses through livestock herd management, stock improvement, fodder development, pasture development, and sustainable livestock insurance schemes.
\end{abstract}

Keywords: Agro-pastoralism, Bhutan, Endangered predators, Herd management, Intensification, Livestock losses, Livestock policy

\section{Introduction}

In contrast to pastoralists whose focus is almost entirely on livestock, agro-pastoralists may focus primarily on agriculture and derive less than $50 \%$ of their income from livestock rearing (Rota and Sperandini 2010). Occupying less arid regions and investing more time in agricultural activities, agro-pastoralists may have higher densities of livestock

\footnotetext{
* Correspondence: pthinley@uwice.gov.bt

¿Ugyen Wangchuck Institute for Conservation and Environment, Bumthang, Bhutan

Full list of author information is available at the end of the article
}

but care less about the quality of livestock as compared to pastoralists (Brandström et al. 1979).

As in many developing countries (Tulachan and Neupane 1999), agro-pastoralism is the major source of livelihood for rural communities in the Himalayan Kingdom of Bhutan. Approximately $90 \%$ of rural farmers raise some form of livestock (RGoB 2009) for dairy products, draught power, meat, and dung (Miller 1987). Livestock rearing is part and parcel of the Bhutanese agricultural system, contributing $7 \%$ of the national GDP and $22 \%$ of rural income (MoA 2009). Most of the livestock belonging to agro-pastoralists are grazed in the 
nearby forests during the daytime and are enclosed in sheds each night. Livestock grazing occurs in almost all forest types (Roder et al. 2002); this is possible, because Bhutan retains about $72 \%$ of original forest cover (DoFPS 2015). Farmers provide pine-needle or oak-leaf bedding for livestock in sheds. Dung from these sheds is then used for crop production, greatly reducing or eliminating the use of chemical fertilizers. Some rural people are transhumant agro-pastoralists (Namgay et al. 2013) who seasonally migrate their cattle from one ecological zone to another (Waters-Bayer and Bayer 1992). Largely influenced by Buddhist traditions, Bhutanese agropastoralists seldom kill their cattle for meat; rather, they are left to die of old age, disease, and accident. Consequently, many farmers end up owning sizable number of cattle, ranging from 1 to 20 but with an average herd size of 6 (Dorji and Gyeltshen 2012).

Due to heavy dependence on livestock rearing for agricultural production, livestock predation by wild predators could form a significant economic setback for rural communities in Bhutan (Sangay and Vernes 2014; Rajaratnam et al. 2015). For instance, between 2003 and 2005, 1,233 farmers lost 1,375 livestock to wild predators (Sangay and Vernes 2008, 2014). Among these affected farmers, 95.9\% reported losing one year's worth of household income, $3.9 \%(n=48)$ two years' household income, and $0.2 \%(n=$ 2 ) three years' household income (Sangay and Vernes 2014). In a case study by Wang and Macdonald (2006) in Jigme Singye Wangchuck National Park (located in central Bhutan), farmers lost $2.3 \%$ of their livestock to wild predators which amounted to $10 \%$ loss of per capita cash income. Such proportions of losses are huge considering the average per capita income of Bhutan, approximately US $\$ 2,230$, based on the 2014 gross national income and population estimate (NSB 2015a).

While livestock losses to wild predators are duly acknowledged, Bhutan cannot resort to any dramatic population reduction of the major wild predators, because most of them are globally threatened according to the IUCN's Red List of Threatened Species (Rajaratnam et al. 2015). The tiger Panthera tigris, snow leopard Panthera uncia, and dhole (Asiatic wild dog) Cuon alpinus are 'endangered' while the common leopard Panthera pardus is 'vulnerable'. These predators occur at the top of the food chains in many ecosystems and are thus vital for overall ecological integrity and ecosystem services such as control of crop-depredating herbivores (Wangchuk 2004). In addition, Bhutan is internationally recognized for its exemplary conservation policy that ensures the survival of a suite of threatened mammalian predators (NBC 2014).

Globally, livestock depredation is a great cause of tension between humans and wild carnivores (Mazzolli et al. 2002; Ogada et al. 2003; Namgail et al. 2007; Tamang and Baral 2008). Bhutan also faces the challenge of a typical biodiversity-rich country in having to juggle socioeconomic needs of farmers with ecological conservation. Wildlife conservationists, on the one hand, fear the loss of endangered wild predators through possible retributive killings while the farmers, on the other hand, complain about their livelihood losses because of livestock depredation by wild predators (NCD 2008; Rajaratnam et al. 2015). In an attempt to appease the afflicted cattle owners, the government through the Wildlife Conservation Division under the Department of Forests and Park Services compensated livestock losses to tigers and snow leopards (Sangay and Vernes 2008) until the end of 2014. However, due to limited funding, the government is currently not in a position to continue such an appeasement scheme and there is currently a huge backlog of cases (Sonam Wangchuk pers. comm.). Such a time lag in compensation has created more displeasure among the livestock owners (Leki, pers. comm.).

Despite the acknowledgement of persistent livestock losses to wild predators, there has been very little information about how livestock herding practice is related to livestock depredation by wild predators. Therefore, the objectives of this study were to (a) assess the current livestock herding practices in terms of their vulnerability to predation by wild predators and (b) suggest appropriate policy recommendations to minimize livestock losses to wild predators.

\section{Study area}

We conducted the study in three western dzongkhags $^{1}$ of Bhutan, namely, Thimphu, Punakha, and Gasa (Figure 1). We selected two geogs ${ }^{2}$ from each of these dzongkhags: Kawang and Genye from Thimphu, Shengabjimi and Lingmukha from Punakha, and Khatoe and Khamoe from Gasa (Figure 1). These areas were selected based on the current reports of high number of livestock depredation cases. To aid understanding, brief profiles of each geog are provided.

\section{Kawang and Genye Geogs in Thimphu Dzongkhag}

Kawang Geog, with an area of $308 \mathrm{~km}^{2}$, is situated in the peri-urban area of Thimphu Municipality. The geog has a population of approximately 2582 people (OCC 2005), 352 cattle, 9 horses, and 299 poultry (DoL 2013). Livestock rearing is considered an important part of people's livelihood in the geog, as most people engage in commercial farming of vegetables that are sold in Thimphu markets. In the upper part of the geog bordering the south-western part of Jigme Dorji National Park (JDNP), numerous cases of livestock predation by tiger, leopards, and dholes have been recorded. With most of the villages located between Bhutan's capital and pristine forest of JDNP, Kawang Geog presents a unique case of how livestock are managed and are rendered vulnerable to predation by wild predators. 


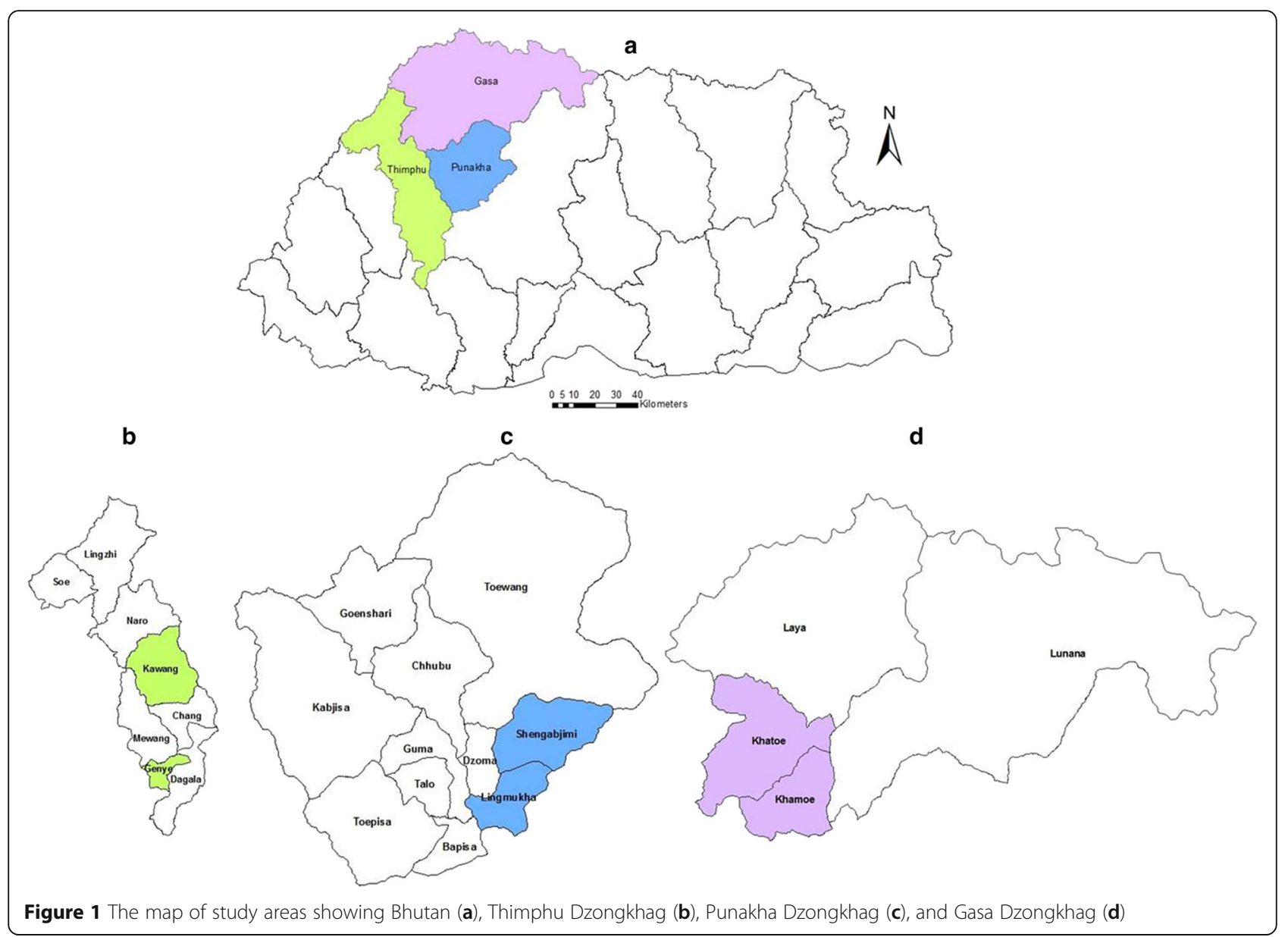

Genye Geog is located in the southernmost part of Thimphu Dzongkhag. Encompassing $144 \mathrm{~km}^{2}$, the geog is thinly populated with only 918 people and 160 households (OCC 2005). Most of the people in the geog subsist on agricultural farming. Their main cash crops are rice, wheat, potato, and other vegetables. They also derive additional income from the sale of matsutake, which is an expensive mushroom mostly exported to Japan and Singapore. People in the geog rear livestock mainly for farmyard manure and dairy products. At present, the geog has 658 cattle, 86 equines, 4 pigs, 1,961 poultry, 9 goats, 150 cats, and 143 dogs (DoL 2013).

\section{Shengabjimi and Lingmukha Geogs in Punakha Dzongkhag}

Shengabjimi Geog has 1,257 people and 284 households (OCC 2005). The annual livestock statistics of 2013 recorded 932 cattle, 12 horses, 7 pigs, 276 poultry, and 8 goats (DoL 2013). Most of the cattle in the geog are of indigenous breed. The principal crops grown in the geog are paddy, wheat, and vegetables. There is a possibility for farm mechanization, as some of the agriculture lands have gentle slopes.
Lingmukha Geog is comparatively small with an area of only $33.8 \mathrm{~km}^{2}$. Due to many low-lying areas, the geog experiences a sub-tropical climate featured by cool winters with warm and humid summers. The geog has 597 people belonging to 124 households (OCC 2005), and the livestock statistic stands at 541 cattle, 60 horses, 6 pigs, and 43 poultry (DoL 2013).

\section{Khatoe and Khamoe Geogs in Gasa Dzongkhag}

Khatoe Geog covers an area of $326 \mathrm{~km}^{2}$, most of which are rugged mountains. In terms of human population, the geog is a low populated part of the dzongkhag, as it has only 426 people and 60 households (OCC 2005). The geog has 210 cattle, 62 horses, and 201 poultry (DoL 2013).

Khamoe Geog is located in the southernmost part of Gasa Dzongkhag, and it is the smallest (encompassing only $149.28 \mathrm{~km}^{2}$ ) of the four geogs in the dzongkhag. It is the least populated geog in the dzongkhag with only 320 people and 81 households (OCC 2005). Aside from Lunana and Laya Geogs, Khamoe is also a livestock priority area in the dzongkhag. The livestock population comprises 540 cattle, 95 horses, and 292 poultry (DoL 2013). 


\section{Methods}

\section{Study design}

We divided our study into two parts: questionnaire survey and field survey. We first undertook the questionnaire survey in late winter and early spring (from December to February 2014), for which we interviewed farmers about their livestock herding practices and losses using a semistructured questionnaire. We conducted the survey at the household level, and only one member of a household (usually the household head) was interviewed. Not all households in the selected geogs owned livestock, as per the Geog Livestock Extension Officers. Some did not even engage in farming as a main source of livelihood. Hence, from a population of households that owned livestock in each geog, we randomly selected $30 \%$ for interview to ensure adequate representation. Next, we pursued the field survey in late spring, summer, and early autumn (from April to August 2015) by walking along human trails in the forests surrounding the villages to verify and gain further insights into local herding practices. Using toposheets and Google ${ }^{\mathrm{TM}}$ Earth, we mapped all major human trails and planned our hiking dates. We triangulated information from both these surveys to form an opinion about livestock vulnerability to predation.

\section{Data collection}

For the questionnaire survey, we interviewed 288 households: 29 from Kawang Geog, 72 from Genye Geog, 52 from Lingmukha Geog, 47 from Shengabjimi Geog, 15 from Khatoe Geog, and 73 from Khamoe Geog. We particularly interviewed the household heads on different aspects of livestock management: types of livestock breeds owned, types of livestock herding practices, reasons for herding or not herding, quantity and breed of livestock lost to wild predators in the past three years (2012 to 2014), and whether the livestock were herded or not herded when lost to predators. Additional household members were consulted when the key informants could not answer some of the questions. We conducted the interview mostly in the evening when farmers retired to their homes, so that there was a high chance of meeting the household heads.

Regarding the field survey, we took note of the number of livestock encountered in different forest types and checked whether they were accompanied by herders or left on their own. We also noted the geographical coordinates of livestock animals using Global Positioning System units. The data were collected from February 2015 to September 2016.

\section{Data analysis}

We used the programme $\mathrm{R}$ version 3.1.3 ( $\mathrm{R}$ Core Team 2015) for statistical analysis. Descriptive statistics were first performed to look for patterns in the data, which were then verified using inferential statistics. We performed a Kruskal-Wallis test to examine statistically significant differences in the number of households practising different livestock herding practices and also differences in the number of livestock lost to different types of different predators. Post hoc analysis of Kruskal-Wallis test using the r package 'pgirmess' version 1.5.9 (Giraudoux 2014) was used to further determine any significant differences between a particular pair of herding practices in terms of number of households and also between a pair of wild predators in terms of number of livestock lost. We performed MannWhitney $U$ test to check if there was statistically significant difference between these variables: (a) quantity of livestock lost to predators when herded and not herded, (b) quantity of indigenous and imported cattle breeds lost to predation, and (c) quantity of cattle and equines lost to predation.

We used ArcGIS ${ }^{\mathrm{TM}}$ and Google ${ }^{\mathrm{TM}}$ Earth to analyse the field data. In order to compute the distances of livestock animal locations from human settlements, we first extracted the settlement boundaries inclusive of crop field boundaries from Google Earth. This settlement layer was then added in ArcMap on which the geo-referenced animal locations were also added. Using the 'distance' tool in ArcMap, we recorded the distance of each animal location from the nearest settlement boundary. We also computed livestock encounter rate in the forest as the number of animals encountered per kilometre of trail walked, in order to obtain a coarse estimate of livestock density in the forest.

\section{Results}

\section{Livestock types and breeds raised}

In the study area, farmers raised five types of livestock cattle, horse, pig, poultry, and goat - among which cattle was the most preferred type because of its multiple uses. Next to cattle, farmers raised poultry for eggs. Very few households owned horses due to improvements in road and transport facilities. Farmers reported that horses were mainly used for transportation of goods in very remote areas without roads or modern transportation facilities and also used in areas of high tourism.

Generally, most of the livestock species were indigenous breeds with the exception of cattle, for which we recorded two imported breeds, viz, Brown Swiss and Jersey, and four local breeds, viz, Siri ${ }^{3}$, Nublang ${ }^{4}$ (Thrabam for female), Jatsha ${ }^{5}$ (Jatsham for female), and Yangka ${ }^{6}$ (Yangkum for female). Nublang is the most endangered native breed and is raised mostly for draught power (Dorji et al. 2009). See Namgay et al. (2013) and Phanchung and Roden (1996) for further description of these breeds.

\section{Types of livestock herding practices}

We classified four general types of livestock herding practices from the responses to our questionnaire survey: (1) Stall feeding (SF) - raised in sheds and never 
taken to the nearby forest for grazing; (2) Free-range grazing with herder (FGH) - left freely grazing in the nearby SRF (State Reserve Forests) but accompanied by a herder; (3) Free-range grazing without herder (FGWH) - left freely grazing in the nearby SRF without a herder; and (4) Free-range pasture grazing (FPG) - left freely grazing in a fenced pasture land but without a herder. Cattle and horses were released to the nearby forests during daytime and were brought back to their sheds near human houses in the evening. Bulls spent most of their time in the forests and were only brought to settlements during ploughing season.

The majority of respondents practised FGWH $(45 \% ; n$ $=128$ ) while only $16 \%$ practised FGH, followed by SF (7\%) and FPG (1\%). Eighteen percent followed a combination of SF and FGWH depending on the availability of feed, and 14\% followed a combination of FGH and FGWH depending on the availability of herders or manpower during intense farm works and when there was news of predator presence in the nearby forests. These herding practices were significantly different in terms of number of households practising them at 0.05 significance level $\left(H_{(4)}=\right.$ 93.37, $p<0.005)$. Post hoc analysis showed the number of households practising FGWH was significantly higher than those practising FGH $(p<0.005)$.

Among the cattle breeds, the high-yielding breeds such as Jersey and Brown Swiss and the milking cows of other breeds were stall-fed, whereas the bulls and the unproductive local breeds were left freely grazing in the nearby forests without herders. Most farmers said that horses and mules were occasionally left grazing in the forests without herders in times of urgent household situations. Otherwise, they were either stall-fed or released into areas close to settlements, because they were very expensive. Goats and poultry were also stall-fed.

\section{Seasonal difference in herding practices}

Most of the cattle were tended well during winter and early spring when farmers were freed of farming work and fodder was scarce in the forests. Animals were fed with dried grasses, straw, kitchen wastes, and stock-piled vegetables mostly pumpkin, radish, and turnip. Some were tethered in crop fields to feed on paddy stumps and dried grasses during winter season, immediately after the harvest. Contrastingly, in summer and early autumn when fodder was plentiful in the forests and when farmers were heavily engaged in agricultural works, cattle were mostly left freely grazing in the forests on their own. It was during such seasons cattle were highly vulnerable to wild predators.

\section{Principal reasons for not herding}

When asked about the principal reasons for not herding their cattle, almost $90 \%$ of the respondents said that they would herd their cattle irrespective of breed or season if they had adequate manpower. However, most of the households cited acute shortage of labour in their villages due to rural-urban migration and increased enrolment of all their kids in the schools as mandated by the government's policy of 'no child left behind'. Shortage of labour is the main reason why most of the cattle herders are either too old (some even in their 80s) to work in the agricultural fields or they are mentally and physically challenged, because of which cattle could be vulnerable to predation. Another important reason farmers (8\%) gave for not herding was the lack of adequate pastureland. Only a few respondents (2\%) stated it was an ageold tradition to leave their cattle freely grazing in the forests, completely unattended by humans.

\section{Livestock in the forests}

During our trail transect surveys in forests surrounding villages, we encountered a total of 1,050 cattle and only 10 horses. We walked a total transect length of $150 \mathrm{~km}$, and the livestock encounter rate was 7.07 livestock $/ \mathrm{km}$ of trail walked. Sixty-five percent of cattle we encountered were foraging in deep jungle more than $2 \mathrm{~km}$ from the nearest village boundary. The farthest distance recorded was $3 \mathrm{~km}$, and such areas were occupied by bulls (Figure 2). Horses were sighted closer to human settlements, within $1 \mathrm{~km}$ from the nearest village boundary.

Of the total cattle encountered in the nearby forests, only $14.3 \% \quad(n=150)$ were accompanied by herders (Figure 3$)$, with the rest $85.7 \%(n=900)$ left to range freely. All 10 horses freely grazing in the forests were also not accompanied by herders. More than $80 \%(n=120)$ of those cattle accompanied by herders were situated closer to human settlements, mostly within $1.5-\mathrm{km}$ distance from the settlement boundaries.

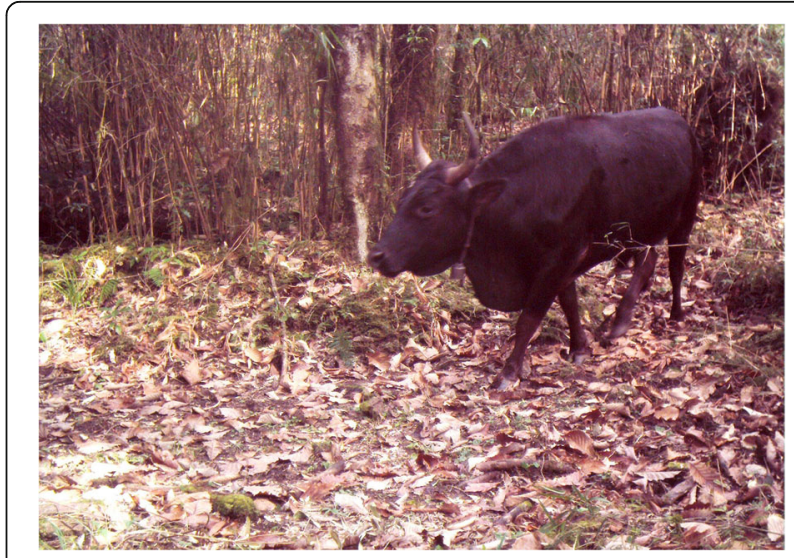

Figure 2 A free-ranging bull foraging in the deep jungle, far away (about $3 \mathrm{~km}$ ) from human settlement 


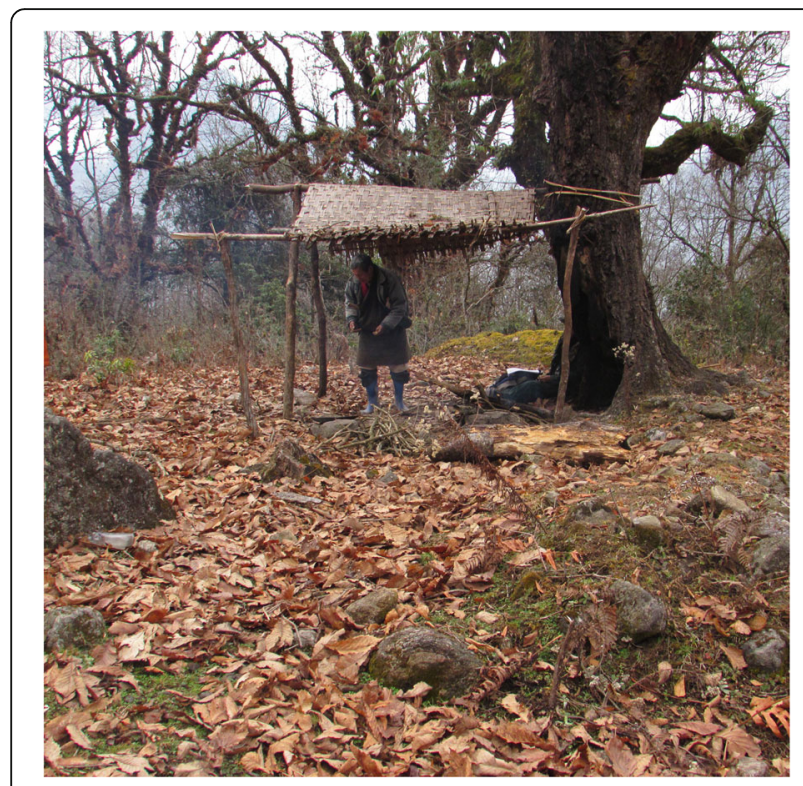

Figure 3 A cattle herder in Gasa Dzongkhag posing in front of his makeshift camp in a temperate broadleaved forest

\section{Livestock losses to wild predators}

Farmers lost 355 animals, mostly horses and cattle, during the period 2012 to 2014 to four main wild predators: $177(49.9 \%)$ to dhole, 121 (34.1\%) to common leopard, $38(10.7 \%)$ to tiger (Figure 4), and $19(5.3 \%)$ to Asiatic black bear Ursus thibetanus. There was significant difference in the number of livestock killed by each predator $\left(H_{(3)}=74.68, p<0.005\right)$, largely driven by dhole. The number of animals lost to different predators differed between the geogs. For example, Lingmukha Geog lost most of the livestock to leopards while Genye, Khatoe, Khamoe, and Shengabjimi lost most of their livestock to dholes (Table 1). Predation losses also differed among

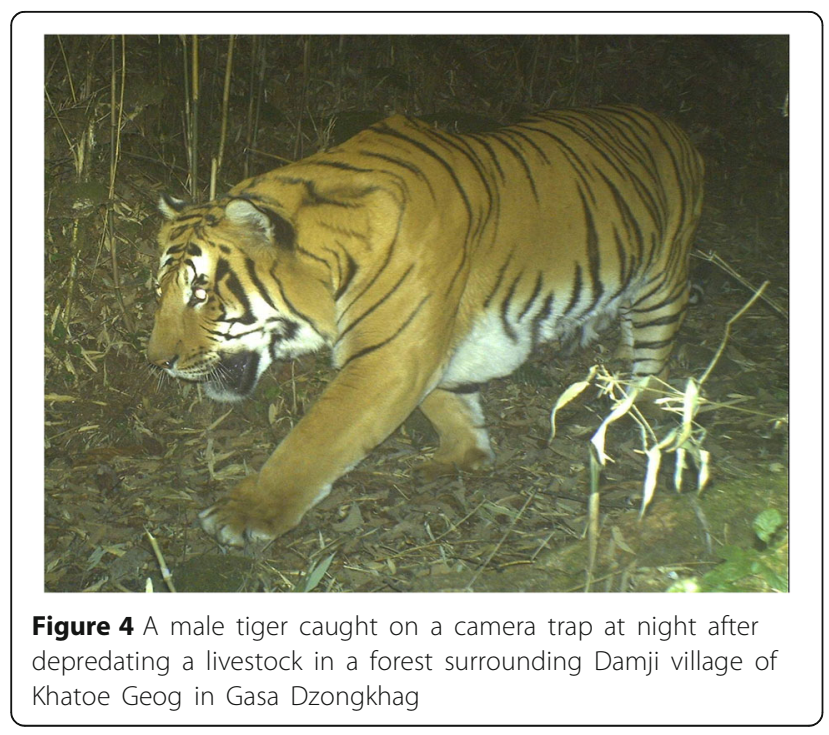

Table 1 Number of livestock lost to different predators in different geogs in the study area from 2012 to 2014

\begin{tabular}{lllllll}
\hline Geog & Dzongkhag & Dhole & Leopard & Bear & Tiger & Total \\
\hline Lingmukha & Punakha & 31 & 71 & 0 & 3 & 105 \\
Shangabjimi & Punakha & 6 & 5 & 0 & 5 & 16 \\
Genye & Thimphu & 49 & 11 & 12 & 1 & 73 \\
Kawang & Thimphu & 5 & 8 & 0 & 0 & 13 \\
Khatoe & Gasa & 16 & 2 & 0 & 2 & 20 \\
Khamoe & Gasa & 70 & 24 & 7 & 27 & 128 \\
Total & & 177 & 121 & 19 & 38 & 355 \\
\hline
\end{tabular}

livestock type and breed (Table 2). The number of cattle lost was significantly higher than the number of equines (horses and mules) lost $\left(U_{(1)}=76.18, p<0.005\right)$. Equines were mostly lost to leopard and none to bears. Among cattle breeds, Siri was the most predated. The number of indigenous breeds lost was significantly higher than the imported breeds $\left(U_{(1)}=78.08, p<0.005\right)$. The great majority of livestock were lost when they were not herded (92\%) in comparison to livestock that were herded (8\%; Figure 5), and the difference was statistically significant $\left(U_{(1)}=129.27, p<0.005\right)$.

\section{Discussion}

\section{Livestock vulnerability among herding practices}

Livestock in general are more vulnerable to predation than their wild counterparts, because they may have lost their natural instinct to effectively fend off the predators (Polisar et al. 2003) as a result of domestication. We determined that livestock generally released to the nearby forests for grazing (FGH and FGWH) were more vulnerable than those stall-fed (SF) and kept within some enclosures (FPG). We based this assessment from the manner in which predators took livestock. In Bhutan, large predators, except leopards, rarely come to the human settlements to take away livestock. There have been incidences of tigers coming near animal sheds in human settlements when they were too old to hunt wild prey (Kuensel, 2005). However, the success rate of livestock capture from such behaviour was

Table 2 Number of livestock lost to wild predators by type and breed in the study area from 2012 to 2014

\begin{tabular}{llllll}
\hline Livestock type & Breed & Dhole & Leopard & Bear & Tiger \\
\hline Cattle & Jersey & 10 & 5 & 3 & 5 \\
& Siri & 100 & 75 & 7 & 15 \\
& Brown Swiss & 5 & 1 & 0 & 0 \\
& Jatsha & 17 & 5 & 0 & 8 \\
Horse & Yangka & 34 & 5 & 7 & 4 \\
Mule & Indigenous & 6 & 21 & 2 & 1 \\
\hline
\end{tabular}




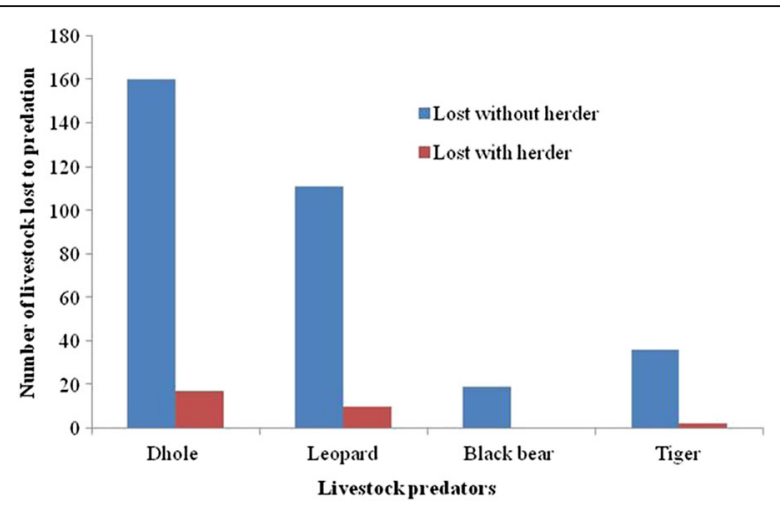

Figure 5 A graphical depiction of difference in livestock losses to wild predators by herding practice from 2012 to 2014

very low. Leopards are known to come very close to human houses but usually in order to hunt domestic dogs.

Further, we considered livestock left freely grazing in the forests without accompanying herders (FGWH) more vulnerable than those with herders (FGH). This was because the number of livestock lost to predators when not herded was significantly higher than when herded. Ogada et al. (2003) also noticed closely herded livestock were less likely to be killed by African carnivores. Moreover, $65 \%$ of the free-ranging animals were released farther than 2-km distance from the human settlements which rendered the animals easy prey to wild predators. Large carnivores normally select wild herbivores if available in adequate number (Treves and Karanth 2003; Ogara et al. 2010), but they turn to domestic livestock in livestock-dominated landscapes (Rajaratnam et al. 2015), especially if livestock are left to range freely without herders (Meriggi et al. 1996).

Seasonally, livestock were more vulnerable during summer and early autumn because during this peak farming season, livestock are often released to range freely in the nearby forest, according to farmers. In winter and early spring when farmers were free from farm work, livestock were less vulnerable because farmers tended them more intensively and they were kept nearer to cleared farmlands and sheds (Thinley et al. 2011). Such a seasonal pattern of livestock loss was also noted by Sangay and Vernes (2008) while analysing livestock depredation cases reported from all over Bhutan from 2003 to 2005. A comparable study by Jackson et al. (1996) in Nepal also reported that depredation losses peaked in late spring and early summer (April to June). Similarly, Dar et al. (2009) reported that the majority of livestock killed by leopard in Pakistan's Machiara National Park occurred during the summer months of May and July.

\section{Livestock vulnerability among type, breed, and sex}

Among livestock types, we determined cattle to be the most vulnerable to predation, probably because cattle were released into the nearby forests more frequently and are mostly not herded. We also found indigenous breeds of cattle more vulnerable to predation than the imported high-yielding breeds based on herding practices and the significant quantity of indigenous breed lost to predation as compared to imported ones. Because imported breeds were more expensive, they were usually stall-fed. Thus, they were seldom lost to predators, except for some bulls which were let loose into the forest during farming seasons, whereas indigenous breeds were mostly released to the nearby forests. Bulls of indigenous breeds, particularly Jatsa and Nublang, were more vulnerable to predation than cows, because they were mostly left in the forests, far away from the homesteads during non-ploughing periods (Figure 2). This was determined from herding practice and observation in the field. Non-milking cows were more vulnerable than the milking cows because the latter were stall-fed until the calves were fully weaned.

\section{Importance of proper livestock herding and its challenges} Our study underscores the importance of proper livestock herding, meaning assignment of herders to accompany livestock in forests, to minimize predation losses (Wang and Macdonald 2006; Rajaratnam et al. 2015). In Bhutan, due to the short supply of fodder and small per capita landholding averaging less than half an acre (NSB 2015b), people are compelled to release their livestock, especially cattle, to the nearby forests for grazing (Wangchuk et al. 2014). Such a situation naturally predisposes livestock to predation. But, careful analysis of the herding dynamics showed that if livestock were properly herded within the forests with accompanying herders, predation losses could have been reduced irrespective of type, breed, and sex.

Thus, our study has shown that livestock, irrespective of breed and type, were more vulnerable to predation when not herded than herded. This highlights the importance of proper tending of livestock if predation losses are to be minimized. Therefore, to minimize livestock predation, Bhutanese agro-pastoralists would need to appoint livestock herders to accompany animals released into the forests. However, this is challenging due to shortage of rural farm labour resulting from rural-urban migration and increased enrolment of children to schools (Wangchuk et al. 2014). Increased enrolment of children is one of the key drivers of rural-urban migration. Bhutanese youths seek employment in urban areas which is deemed as more rewarding with higher income than the laborious farm work in the villages (Dosch 2011). But, not all youth are employed due to limited employment opportunities in the government and private sectors. The youth employment rate as of 2014 is 92.7\% (Tenzin 2015). Although several initiatives are taken by the government to attract educated youth to take up farm labour, the progress has been very slow. Therefore, 
there is a need to revisit the government's policy of $100 \%$ enrolment to schools. The farm labour shortage is also a factor that drives rural people to migrate to urban areas in search of higher income opportunities (Dosch 2011).

\section{Implications for livestock management policy}

While we acknowledge the challenges of appointing cattle herders in rural areas, we have shown that low-value domestic breeds are more vulnerable to predation than the high-value imported ones, simply because the latter are tended better. Hence, livestock losses could be minimized further if the number of scrub cattle could be reduced through animal stock improvement programmes such as promotion of high-yielding breeds (Katel et al. 2015) through breeding bull supply and artificial insemination. The Department of Livestock has been carrying out such programmes (Spierenburg et al. 2004), but they need to be rigorously pursued in livestock depredation hotspots. Such a move is feasible, because some villages in central and western parts of Bhutan have shown a strong inclination towards raising small and productive cattle herds (Wangchuk et al. 2014). However, the trade-offs with shifting to exotic breeds, particularly the potential loss of genetic diversity resulting from loss of indigenous breeds (Barker 2001), need to be considered. We suggest maintaining small and manageable cattle herds with a balance between high-yielding exotic and low-yielding native breeds. It may be argued that stall feeding of exotic breeds may take up farmers' time and space, but farmers themselves have mentioned that stall feeding is much easier than dropping off and rounding up cattle from the forests.

In addition, we have found lack of adequate pasture as another important reason for not herding livestock. Therefore, in conjunction with stock improvement, farmers could be leased with some portions of the SRF for development of pasture lands (Wang and Macdonald 2006) with proper management guidelines, including the prescriptions of proper fencing and corralling facilities. High-yielding and more nutritious varieties of fodder crops could be grown in the pasture lands, as also suggested by Spierenburg et al. (2004) and Tamang and Baral (2008). The feasibility of allocating grazing lands from the community forests could be explored as well. This policy has gained relevance in recent times because the government has taken back the traditional grazing rights such as registered $t$ samdro ${ }^{7}$ with the intention of improving grazing area management. Simultaneously, farmers could also be educated on the ranging behaviour of the wild predators, as suggested by Tumenta et al. (2013), and on the spatial pattern of their livestock depredation sites, as observed by Thinley (2010).

Bhutan currently lacks a comprehensive livestock management policy that ensures a balance between livestock production and minimizing losses to wild predators. As such, conflicts frequently arise between livestock owners, livestock officers, and wildlife managers. There is a need to develop an inclusive policy that addresses the concerns of both the wildlife managers and livestock holders whose participation will be crucial (Wangchuk 2002). We therefore suggest developing a comprehensive livestock management policy that has elaborate provisions on livestock herd management (requiring accompanying herders while grazing in the forests), stock improvement, fodder development, pasture development, and sustainable livestock insurance schemes. We also reiterate that compensation to livestock owners in any form is an important tool for managing human-predator conflicts in Bhutan (Sangay and Vernes 2014). Further, we have observed in this study that dholes are the dominant livestock predators. We do not recommend culling of dhole populations, because it is an 'endangered' species. In order to avoid massive dhole extirpation as in the 1970s and 1980s (Thinley et al. 2011), we suggest livestock officers and wildlife conservationists to equally prioritize compensating or insuring against losses to dholes as equally as being done for tigers and snow leopards.

\section{Conclusions}

Livestock in general were more vulnerable to predation when released into the forests without accompanying herders, especially during farming seasons. Cattle, particularly the indigenous breeds, were more vulnerable among different livestock types. Proper livestock herding with accompanying livestock herders could minimize predation losses. We recommend development of a comprehensive livestock management policy that will ensure minimal livestock losses to wild predators.

\section{Endnotes}

${ }^{1}$ Dzongkhag is known in the Bhutanese national language, Dzongkha, as an administrative district. Bhutan currently has 20 dzongkhags.

${ }^{2}$ Geog is a Dzongkha term for an administrative block or a sub-district. A dzongkhag can have 4 to 15 geogs. In total, Bhutan as 205 geogs.

${ }^{3}$ Siri is the most common indigenous cattle breed in Bhutan.

${ }^{4}$ Nublang is an indigenous breed which has its origin in Haa Dzongkhag. See Dorji et al. (2009) for elaborate description of this breed.

${ }^{5}$ Jatsha and Jatsham are, respectively, the male and female hybrids of the Mithun (Bos gaurus) and Siri cross.

${ }^{6}$ Yangka and Yangkum are, respectively, the male and female fourth-generation offspring from backcross between Jatsha (or Jatsham) and Mithun or Siri.

${ }^{7}$ Tsamdro is a portion of the State Reserve Forest registered in an individual household's name and inherited by children where the owners can graze their cattle. Currently, the government has revoked the tsamdro rights to develop a policy of scientifically managed grazing lands. 


\section{Abbreviations}

FGH: Free-range grazing with herder; FGWH: Free-range grazing without herder; FPG: Free-range pasture grazing; JDNP: Jigme Dorji National Park; SF: Stall feeding; SRF: State Reserve Forest

\section{Acknowledgements}

We thank the Rufford Foundation for major funding support and the Wildlife Conservation Division of the Department of Forests and Park Services of Bhutan Government for their supplemental funding support and for kindly permitting us to undertake the study. In addition, we acknowledge the help of the livestock extension officers and the district livestock officers of Paro, Punakha, and Thimphu Dzongkhags for their assistance in data collection. Further, we are grateful to Karl Vernes of the University of New England in Australia and Tiger Sangay of the Ugyen Wangchuck Institute for Conservation and Environment for their critical reviews and comments. Lastly, we appreciate the critical comments provided by three anonymous reviewers.

\section{Authors' contributions}

$K T$ collected and organized the field data and helped in partial data analysis and initial drafting of the manuscript. PT helped in study design, supervised the data collection, and assisted in data analysis and final drafting of the manuscript. Both authors read and approved the final manuscript.

\section{Authors' information}

$\mathrm{KT}$ is a Senior Forest Range Officer at Thimphu Territorial Forest Division under the Department of Forests and Park Services, Bhutan. Prior to his transfer to the division, he has worked as a Forestry Extension Agent in Thimphu District. He completed his Bachelor's degree in Forestry from the College of Natural Resources, Bhutan, in 2015.

PT is a Principal Forestry Research Officer at the Ugyen Wangchuck Institute for Conservation and Environment in Bhutan. Completing his Ph.D. from Cornell University in the USA, he specializes in mitigating negative human-wildlife interactions.

\section{Competing interests}

The authors declare that they have no competing interests.

\section{Author details}

${ }^{1}$ Thimphu Territorial Forest Division, Thimphu, Bhutan. ${ }^{2}$ Ugyen Wangchuck Institute for Conservation and Environment, Bumthang, Bhutan.

\section{Received: 20 November 2016 Accepted: 3 February 2017 Published online: 01 March 2017}

\section{References}

Barker, J.S. 2001. Conservation and management of genetic diversity: A domestic animal perspective. Canadian Journal of Forest Research 31: 588-595.

Brandström, P., J. Hultin, and J. Lindström. 1979. Aspects of agro-pastoralism in East Africa. Sweden: Scandinavian institute of African studies Uppsala.

Dar, N.I., R.A. Minhas, Q. Zaman, and M. Linkie. 2009. Predicting the patterns, perceptions and causes of human-carnivore conflict in and around Machiara National Park, Pakistan. Biological Conservation 142: 2076-2082.

DoFPS (Department of Forests and Park Services). 2015. Forestry facts and figures. Thimphu: Kuensel Corporation Limited.

DoL (Department of Livestock). 2013. Livestock Statistics 2013. Thimphu: Department of Livestock, Ministry of Agriculture and Forests.

Dorji, N., and T. Gyeltshen. 2012. Characterisation of family poultry production in Haa and Mongar districts of Bhutan. Livestock Research for Rural Development 24: 155.

Dorji, T., L. Tshering, and D. Rai. 2009. Conservation of the last Himalayan cattle breed of Bhutan. In Potential good practice note. Delhi: South Asia Pro-Poor Livestock Policy Programme (SA PPLPP).

Dosch E. 2011. Validating the culture of agriculture: Farmers groups and organic agriculture mitigating rural to urban migration in Bhutan. Independent Study Project (ISP) Collection. Paper 1064. http://digitalcollections.sit.edu/isp_ collection/1064. Accessed 30 Jan 2017.

Giraudoux P. 2014. pgirmess: Data analysis in ecology. R package version 1.5.9. http://CRAN.R-project.org/package=pgirmess. Accessed 28 Jan 2015.

Jackson, R.M., G.G. Ahlborn, M. Gurung, and S. Ale. 1996. Reducing livestock depredation losses in the Nepalese Himalaya. In Proceedings of the 17th Vertebrate Pest Conference, ed. R.M. Timm and A.C. Crabb, 241-247. Davis: University of California.
Katel, O.N., S. Pradhan, and D. Schmidt-Vogt. 2015. A survey of livestock losses caused by Asiatic wild dogs, leopards and tigers, and of the impact of predation on the livelihood of farmers in Bhutan. Wildlife Research 41: 300-310. Kuensel, Y. 2005. A tiger caught. Kuensel Bhutan's National Newspaper.

Mazzolli, M., M.E. Graipel, and N. Dunstone. 2002. Mountain lion depredation in southern Brazil. Biological Conservation 105: 43-51.

Meriggi, A., A. Brangi, C. Matteucci, and O. Sacchi. 1996. The feeding habits of wolves in relation to large prey availability in northern Italy. Ecography 19: 287-295.

Miller, D.J. 1987. Rangelands of the Himalayan kingdom of Bhutan. Rangelands Archives 9: 257-259.

MoA (Ministry of Agriculture). 2009. RNR census 2008. Thimphu: Policy and Planning Division, Ministry of Agriculture.

Namgail, T., J.L. Fox, and Y.V. Bhatnagar. 2007. Carnivore-caused livestock mortality in Trans-Himalaya. Environmental Management 39: 490-496.

Namgay, K., J. Millar, R. Black, and T. Samdup. 2013. Transhumant agropastoralism in Bhutan: Exploring contemporary practices and socio-cultural traditions. Pastoralism 3: 1-26.

NBC (National Biodiversity Centre). 2014. National biodiversity strategies and action plan of Bhutan 2014, 173. Thimphu: National Biodiversity Centre, Ministry of Agriculture and Forests, Royal Government of Bhutan.

NCD (Nature Conservation Division). 2008. Bhutan national human-wildlife conflicts management strategy. In Department of Forests and Park Services MoAaF, Bhutan, 87. Thimphu: Kuensel Corporation Limited.

NSB (National Statistics Bureau). 2015a. Bhutan at a glance 2015. Thimphu: National Statistics Bureau, Royal Government of Bhutan.

NSB (National Statistics Bureau). 2015b. Statistical yearbook of Bhutan 2015, 292. Thimphu: National Statistical Bureau.

OCC (Office of the Census Commissioner). 2005. Population and housing census of Bhutan 2005. Thimphu: National Statistics Bureau.

Ogada, M.O., R. Woodroffe, N.O. Oguge, and L.G. Frank. 2003. Limiting depredation by African carnivores: The role of livestock husbandry. Conservation Biology 17: 1521-1530.

Ogara, W.O., N.J. Gitahi, S.A. Andanje, N. Oguge, D.W. Nduati, and A.O. Mainga. 2010. Determination of carnivores prey base by scat analysis in Samburu community group ranches in Kenya. African Journal of Environmental Science and Technology 4: 540-546.

Phanchung, and J.A. Roden. 1996. Characterisation of the Siri breed and the Mithun cross Siri in Bhutan. Animal Genetic Resources Information 20: 27-34.

Polisar, J., I. Maxit, D. Scognamillo, L. Farrell, M.E. Sunquist, and J.F. Eisenberg. 2003. Jaguars, pumas, their prey base, and cattle ranching: Ecological interpretations of a management problem. Biological Conservation 109: 297-310.

R Core Team. 2015. R: A language and environment for statistical computing Vienna: R Foundation for Statistical Computing. http://www.R-project.org/. Accessed 12 Dec 2015

Rajaratnam, R., K. Vernes, and T. Sangay. 2015. A review of livestock predation by large carnivores in the Himalayan Kingdom of Bhutan. In Problematic Wildlife: A Cross-Disciplinary Approach, ed. F.M. Angelici, 143-171. Switzerland: Springer.

RGOB (Royal Government of Bhutan). 2009. RNR sector tenth five year plan (20082013): Enabling farming communities to overcome poverty (Vol. I: Main document). Thimphu: Ministry of Agriculture, Royal Government of Bhutan.

Roder, W., G. Gratzer, and K. Wangdi. 2002. Cattle grazing in the conifer forests of Bhutan. Mountain Research and Development 22: 368-374.

Rota, A., and S. Sperandini. 2010. Livestock and pastoralists, 1-8. Rome: Livestock Thematic Papers: Tools for Project Design. International Fund for Agricultural Development.

Sangay, T., and K. Vernes. 2008. Human-wildlife conflict in the Kingdom of Bhutan: Patterns of livestock predation by large mammalian carnivores. Biological Conservation 141: 1272-1282.

Sangay, T., and K. Vernes. 2014. The economic cost of wild mammalian carnivores to farmers in the Himalayan Kingdom of Bhutan. Proceedings of the Ecological Society of Bhutan 1: 98-111.

Spierenburg, P., K. Tshering, and D.S. Rai. 2004. Saving the forest through livestock intensification, 24-25. India: Leisa Magazine. AME Foundation.

Tamang, B., and N. Baral. 2008. Livestock depredation by large cats in Bardia National Park, Nepal: Implications for improving park-people relations. International Journal of Biodiversity Science and Management 4: 44-53.

Tenzin, U. 2015. Micro-characteristics of youth unemployment in Bhutan: A crosssectional study, 87. Thimphu: Labour Market Information and Research Division, Department of Employment, Ministry of Labour and Human Resources. 
Thinley, P. 2010. Understanding the pattern of spatial co-occurrence between tigers, leopards, and black bears in Bhutan through spatial point pattern analysis of their livestock depredation sites. Journal of Renewable Natural Resources of Bhutan 5: 107-119.

Thinley, P., J.F. Kamler, S.W. Wang, K. Lham, U. Stenkewitz, and D.W. Macdonald. 2011. Seasonal diet of dholes (Cuon alpinus) in northwestern Bhutan. Mammalian Biology 76: 518-520.

Treves, A., and K.U. Karanth. 2003. Human-carnivore conflict and perspectives on carnivore management worldwide. Conservation Biology 17: 1491-1499.

Tulachan, P.M., and A. Neupane. 1999. Livestock in mixed farming systems of the Hindu Kush-Himalayas. Trends and Sustainability, vol. 116. Kathmandu: ICIMOD.

Tumenta, P.N., H.H. de longh, P.J. Funston, and H.A.U. de Haes. 2013. Livestock depredation and mitigation methods practised by resident and nomadic pastoralists around Waza National Park, Cameroon. Oryx 47: 237-242.

Wang, S.W., and D.W. Macdonald. 2006. Livestock predation by carnivores in Jigme Singye Wangchuck National Park, Bhutan. Biological Conservation 129: 558-565.

Wangchuk, S. 2002. Grazing management in national parks and protected areas: Science, socio-economics and legislation (tenure). Journal of Bhutan Studies 7 : 61-81.

Wangchuk, T. 2004. Predator-prey dynamics: The role of predators in the control of problem species. Journal of Bhutan Studies 10: 68-89.

Wangchuk, K., M. Wurzinger, A. Darabant, G. Gratzer, and W. Zollitsch. 2014. The changing face of cattle raising and forest grazing in the Bhutan Himalaya. Mountain Research and Development 34: 131-138.

Waters-Bayer, A., and W. Bayer. 1992. The role of livestock in the rural economy. Nomadic Peoples 31: 3-18

\section{Submit your manuscript to a SpringerOpen ${ }^{\circ}$ journal and benefit from:}

- Convenient online submission

- Rigorous peer review

- Immediate publication on acceptance

- Open access: articles freely available online

- High visibility within the field

- Retaining the copyright to your article

Submit your next manuscript at $\gg$ springeropen.com 